\title{
Profitability of Forest Certification - Case Study Analysis
}

\section{Emil Kitchoukov*, Nikola Stoyanov**, Tsvetelina Simeonova-Zarcin ${ }^{* \star *}$, Todor Stoyanov ${ }^{\star \star * *}$}

\begin{abstract}
Forest certification plays an important role in supporting and ensuring sustainable forest management. By November 2017, the FM FSC certified state hunting and forestry enterprises are 72 in number, part of which are included in group certificates of the respective stateowned enterprises in whose territory they are located. Certified forest area in Bulgaria in November 2017 is 1315594 ha. These numbers are growing very fast at the moment.

The main objective of the study is to analyze and evaluate the profitability of introducing the FSC certificate for sustainable forest management. In this respect a case study analysis is carried out at Yundola and Petrohan, which are Training forest enterprises at the University of Forestry Sofia. These two forest enterprises and adjacent state forest and hunting forest enterprises are considered in this case as model forest areas, including certified and subject to certification forest enterprises and typical forest areas with coniferous and deciduous forests.
\end{abstract}

\footnotetext{
* Professor, University of Forestry - Sofia.

* Professor, University of Forestry - Sofia

${ }^{* * *}$ Assistant professor, University of Forestry - Sofia

${ }^{* * * *}$ PhD student, University of Forestry - Sofia
}

The following research objectives were fulfilled in order to achieve the stated goal:

1. Analysis and estimation of the profitability of the implementation of the FSC certificate for sustainable forest management in Yundola Training forests.

2. Analysis and estimation of the profitability of the implementation of the FSC certificate for sustainable forest management in the Petrohan Training forests.

Based on the study and the results obtained, conclusions and recommendations were made on the impact of FSC certification on the activities of certified FSC forest enterprises.

On the basis of a developed model analysis of the profitability of State hunting enterprise Vitinya, a methodology for analysis and assessment of the profitability of forestry and hunting forest enterprises, certified and subject to FSC certification was developed.

Keywords: sustainable forest management, forest certification, profitability, FSC, logging, woodworking.

JEL:

\section{Introduction}

Forests are multifunctional, serving economic, social and environmental purposes. Of all nature resources in Bulgaria the forests present the biggest share and primary 


\section{Articles}

importance. They offer habitats for animals and plants and play a major role in mitigating climate change and other environmental services. The societal benefits of forests, including for human health, recreation and tourism, are high, but often underestimated. Bulgarian forests have essential contribution to rural development and for many regions they are the only source of financial revenues. Forest biomass is currently the most important source of renewable energy for the country. Forests also provide a large range of other products, such as cork, resins, mushrooms, nuts, game and berries.

To deliver these benefits in a balanced way it is necessary to ensure sustainable forest management.

For the purposes of this paper we use the definition for sustainable forest management, developed by Forest Europe in 1993 and subsequently adopted by the Food and Agriculture Organization (FAO) of the United Nations: „The stewardship and use of forests and forest lands in a way, and at a rate, that maintains their biodiversity, productivity, regeneration capacity, vitality and their potential to fulfil, now and in the future, relevant ecological, economic and social functions, at local, national, and global levels, and that does not cause damage to other ecosystems."

Forest certification plays an important role in supporting and ensuring sustainable forest management. It is a voluntary instrument, which uses a set of standards to evaluate and validate the practices of forest management. It ensures and promotes economically viable forest management, in compliance with social standards, while protecting the environment. Forest certification is a direct economic instrument to ensure the sustainable use and management of forest resources.

FSC (Forest Stewardship Council) certification was one of the earliest multi- stakeholder, global commodity ecocertification schemes. Since its inception in 1994, FSC certification has grown steadily. It now stretches across 79 countries covering over 180 million hectares of forests worldwide. FSC is considered an important conservation instrument for industry and civil society, a reference point for procurement and investment decision-making, and a model for credible standard-setting for a wide range of other commodities (1).

WWF (World Wildlife Fund) considers FSC to be the most credible forest certification standard, because it incorporates the strongest environmental and social safeguards, as well as balanced governance and membership. Compared to other forest certification standards, FSC has the most rigorous requirements for safeguarding HCVs (high conservation value), chemical use, community benefits, indigenous rights, stakeholder engagement and transparency. It also contains the most diverse membership, comprised of leading national and international environmental and social organizations, indigenous peoples' organizations, community forestry enterprises, forest industry professionals and corporations (1).

The assessment of the profitability from the introduction of FSC certificate is important for forest operators, as well as their financiers and donors. While there exists literature assessing the costs and benefits of FSC certification for forest enterprises worldwide, which focuses on individual operators as opposed to cross-cutting analyses; and the direct cost of compliance and direct benefits received through market premiums. Little is known about the operational and intangible benefits (and costs) associated with the FSC certification in Bulgaria.

The main objective of the study is to analyze and evaluate the profitability of introducing the FSC certificate for sustainable 


\section{Articles}

forest management. In this respect a case study analysis is carried out at Yundola and Petrohan, which are Training forest enterprises at the University of Forestry - Sofia. These two forest enterprises and adjacent state forest and hunting forest enterprises are considered in this case as model forest areas, including certified and subject to certification forest enterprises and typical forest areas with coniferous and deciduous forests.

The following research objectives were set to achieve the stated goal:

- To analyse and estimate the profitability of the implementation of the FSC certificate for sustainable forest management in Yundola Training forests.

- To analyse and estimate the profitability of the implementation of the FSC certificate for sustainable forest management in the Petrohan Training forests.

- To discuss and compare the obtained results.

\section{Current situation in Bulgaria}

In Bulgaria the forest territories are around $37 \%$ of the country's territory. Approximately $67 \%$ of them are broadleaved forests. Bulgaria is the third richest in biodiversity country in
Europe. There are 3 National parks, 11 Nature parks and more than 700 protected areas in the country (5).

Forest certification in Bulgaria is a voluntary instrument, which is administered by the evaluation and validation of the practices of forest management using a set of standards.

Forest certification system aims to ensure and promote economically viable forest management, in compliance with social standards, while protecting the environment. Forest certification is a direct economic instrument to ensure the sustainable use and management of forest resources. The certification verifies that the management of forest territories is carried out in an open manner, balancing environmental, economic and social benefits.

Currently FSC is the preferred forest certification scheme in Bulgaria with more than 130 users.

Certification bodies award forest management (FM) certification to those forest managers or owners whose practices meet FSC Principles and Criteria. As it is shown on the figure below, FM certification rose from 1,084 certificates in 2012 to 1,462 certificates in 2017. This is a significant 35 per cent rise over five years.
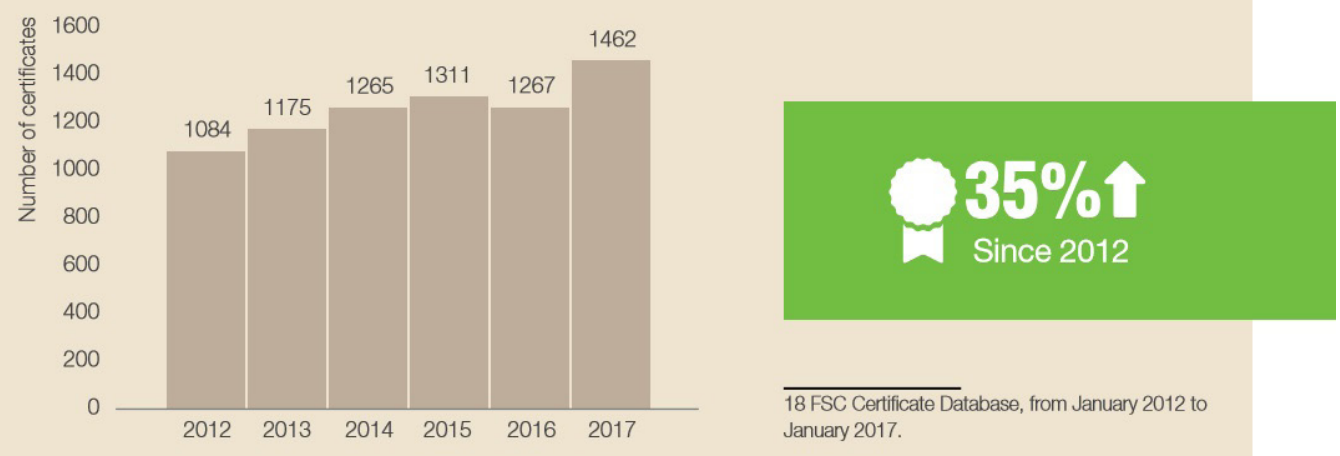

Figure 1. Evolution of FSC FM certificates, 2012-2017

Source: A review of Forest Stewardship Councilß (FSC尺) market developments, statistics, and trends. January 2017 


\section{Articles}

There are 19 forest management enterprises, which have received the FSC forest management certificate in Bulgaria. There are 807833,80 ha of certified forest territories which represent $19 \%$ of the total forest territory of the country. Figure 5 reveals how the FSC certified territories are growing
Profitability of Forest Certification - Case Study Analysis during the years. The first two certificates were awarded in 2006. As it could be seen on the chart, there has been a tendency of growing interest to the certificate over the past few years. At least another three forest management enterprises are under certification procedures.

\section{Territory in ha}

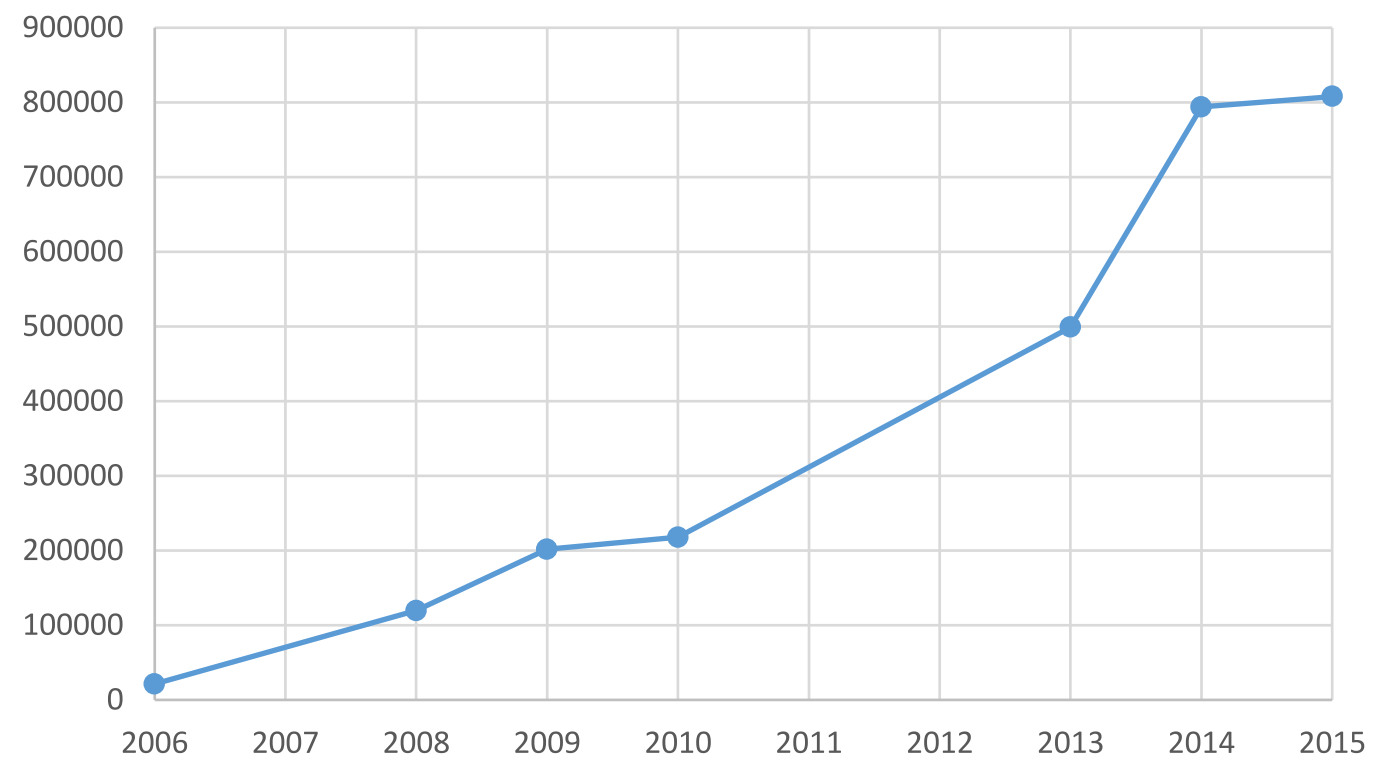

Fig.2. Changes of FSC certified forest territories

Source: Summarized from data on http://info.fsc.org

Figure 3 shows the distribution of FSC territories according to ownership. Most of the forest management enterprises are state-owned forest territories - $98 \%$. There is only one certified municipality. The private sector is represented only by one company which owns relatively small territory of forest plantation. In this respect the forest certification is considered as a state policy in Bulgaria at the moment.

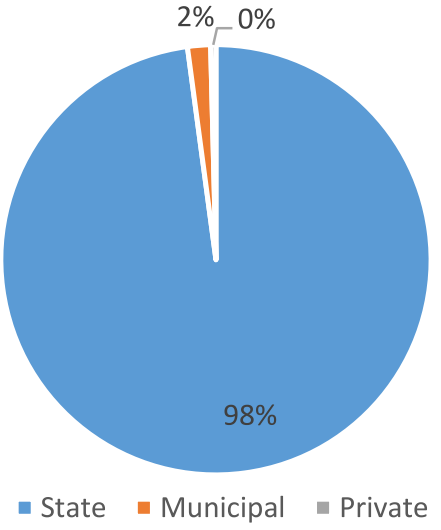

Fig.3. Distribution of FSC certified forest territories according to ownership

Source: Summarized from data on http://info.fsc.org 


\section{Articles}

Certification is one of the fastest-growing "soft political mechanisms" that can be used to support the movement of the forest sector along the lines of sustainable development principles (4).

Forest certification is a partnership between environmentalists who are concerned about forest quality and biodiversity maintenance and forestry professionals who want to find ways to increase the market for environmentally friendly forest products.

An independent forest management certificate saves buyers or investors the inconvenience of confirming that their products come from well-managed forests. The certificate provides a seal of confidence on the market.

The IAG values the need for rapid and adequate introduction of forest certification in Bulgaria. As a government institution directly involved with the management and management of forests in Bulgaria, it creates all the necessary conditions for starting and implementing this process.

The Forestry Act of March 2011 has developed a special section (III) - "Forest Certification".

Market access is the key direct financial benefit of certification. It is closely linked to the recent phenomenon of market globalization. $A$ piece of research carried out by the authors shows that only $47 \%$ of Bulgarian certified forest management enterprises recognize this benefit.

An official survey of FSC shows that the percentage increase in $\mathrm{CoC}$ certificates in Bulgaria for the last two years is $49 \%$ and worldwide only in Ukraine we could see a higher increase. This suggests that the demand for certified timber will increase in the country.

A study and comparative analysis of other forest enterprises with similar characteristics and location as the surveyed shows the following (2):

- Certified forest enterprises are right to evaluate their decision and are pleased with the results.

- The price of certified wood does not differ significantly from that of the uncertified.

- The main advantages of certification are the preservation of market positions and a competitive advantage as well as a better reputation and relations with the local population.

- In the future, an increase in the demand for certified timber in the region of Yundola and Petrohan may be expected. Training forests can benefit from this by going through the certification process.

\section{Methodology}

Coefficients of profitability used in the study are the ones commonly used of the profitability of costs and revenues, including the certification costs. In the current paper the structure of expenses and revenue are transformed to reflect the Bulgarian circumstances. According to Simenonova Zarkin et. al. (2018), the Bulgarian forest legislation covers more than $85 \%$ of the requirements of the FSC. The main expenses are pre-certification costs. From the postcertification costs, the main ones are for annual auditing. At the same time the studies do not offer a profound examination of the whole range of the expenses that emerged following certification. In fact, the Planning, procedures and inventory assessment before and after certification are activities well established in Bulgarian forest legislation, but other activities are not so. Structure of Chain of Custody certification under FSC has the costs structure revealed by Breukink et. 


\section{Articles}

al. (2015), and there are no records for any different one.

The methodology in the current study is based on costs structure for certification, proposed by Breukink et. al. (2015). The authors derived results for the sample of forest operators in more than 80 countries in North and South America. They derived a costs structure that can be used as basement for developing the studies in other countries. The costs structure of pre-certification and post-certification costs are the following (Breukink et. al.,2015):

Pre-certification costs structure: Planning, procedures and inventory - 28\%; Initial FSC audit - 16\%; Pre-assessment or pre-audit - 14\%; Environmental and social impact assessment (ESIA) - 14\%; Safety equipment - 12\%; Others - 16\%

Post-certification cost structure: ESIAs, monitoring, mitigation - 37\%; Benefits to workers - 20\%; Recurring audits - 11\%; Planning, procedures, and inventory - 7\%; Staffing for certification - 7\%; Others - 18\%

\section{Results and Discusion}

\section{Profitability assessment of the} implementation of the FSC certificate in Yundola Training forests

According to the adopted classification scheme of the forest habitat types, the territory of the Yundola training forests falls entirely within the Thracian forest-growing area. Although the territory of the forest enterprise is situated in two subregions (Rila and Western Rhodopes), the natural vegetation is mainly of coniferous species - pine, spruce and fir in different proportions. Significant differences exist in the vertical distribution of plantations.
Profitability of Forest Certification - Case Study Analysis

\section{Distribution of the forest territories in}

Yundola training forest by wood species

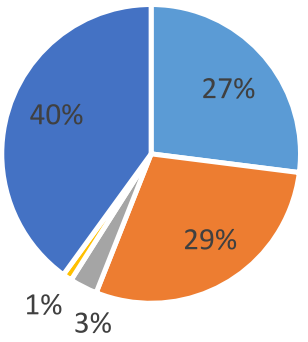

- Silverfir $\backsim$ Spruce $\backsim$ Beech $\backsim$ Other $\square$ Pine

Fig. 4. Distribution of the forest territories in Yundola training forest by wood species

Source: Yundola training forest documentation

Everywhere in the area under consideration dominate coniferous forests, most of which are state-owned.

The average age of the plantings is around 60 years. The total average gain of 1 ha is over $4.5 \mathrm{~m} 3$. The average stock of 1 ha is over $300 \mathrm{m3}$, the average yield is III (2.9) and the average fullness is 0.77 .

The difficult mountainous relief limits the development of the forest infrastructure, which contributes to the preservation of compact, intact forest massifs and is a prerequisite for the diversity of plant and animal species, as well as for their preservation.

The variety of soil conditions as well as the climate of the region contribute to the formation of high-productive forests, as well as to forests with a high degree of biodiversity.

The authors have obtained the following results for the training forest enterprise Yundola, based on the official financial data collected from the unit for 2016:

- Profitability of logging:

- Profitability based on cost - $71.55 \%$

- Profitability based on revenue $41.71 \%$

- Profitability of woodworking:

- Profitability based on cost - $35.36 \%$ 


\section{Articles}

- Profitability based on revenue $26.12 \%$

As it could be seen that the profitability of the logging is higher in comparison to that from woodworking.

The above results show that the profitability of the forestry activity is high and the cost basis is $71 \%$, whereas for woodworking works it is around $35 \%$. Profitability on a revenue basis is naturally a bit lower, but it is still at relatively high levels above $40 \%$ for timber and $26 \%$ for woodworking.

The obtained results show explicitly that the implementation of FSC Forest Management certificate will be of profit and should be recommended.

\section{Profitability assessment of the implementation of the FSC certificate in Petrohan Training forests}

The territory of the Petrohan training forests covers a wide range of altitudes (from 301 to $1900 \mathrm{~m}$ above sea level) and falls into two zones with five subspecies (according to the forestry zoning of the country).

No significant change in the ratio of tree species is expected. In the future, the basic wood species will be preserved - beech, which fully corresponds to the potential opportunities of the formed habitats and well performing its water and protective functions.

In Bulgaria, beech forests have an important economic importance for the forestry sector, providing around a quarter of the total annual timber yield. Their environmental role and their contribution to providing drinking water for the population is enormous. Over $60 \%$ of the area of beech forests falls into the water catchment areas of the country. A significant part of them is included in the protected area system and more than $3 / 4$ are part of the Natura 2000 ecological network.

Areas with a predominance of beech forests are a desirable place for recreation and different types of tourism as there is a rich wildlife and enormous biodiversity. The beech forests are a source of significant nonwood products - healing plants, mushrooms, fruits, fodder.

The authors have obtained the following results for the training forest enterprise Petrohan, based on the official financial data collected from the unit for 2016::

- Profitability of logging:

- Profitability based on cost - $185 \%$

- Profitability based on revenue - 65\%

- Profitability of woodworking:

- Profitability based on cost - 9.8\%

- Profitability based on revenue - $8.9 \%$

These results suggest that the cost-based profitability for the logging activity is $185 \%$, which is very high and is more than two times higher than that of Yundola Training forests.

On the other hand, unlike the Yundola Training forests, at the woodworking works is too low $-9.8 \%$.

Profitability on a revenue basis is naturally lower, but it is still at a very high level above $71 \%$ in the timber industry, while the woodworking is again too low under $9 \%$.

This obtained results show explicitly that the implementation of FSC Forest Management certificate will be of profit and should be recommended.

\section{Conclusion}

Currently FSC is the preferred forest certification system in Bulgaria. FSC shares the EU Commission's broad goals of setting up a better global timber trade and governance system. It promotes sustainable forest management, improves forest governance and supports sustainable consumption.

The final results of the analyses and the quantitative estimates of the incomes with the introduction of a certified Sustainable Forest Management System show that the profitability of the forestry activity in both 
forest enterprises is high and that the cost basis is above $70 \%$ for the Yundola Training forests, and for the woodworking works goes beyond $35 \%$. Profitability on a revenue basis is naturally a bit lower, but it is still at relatively high levels above $40 \%$ for timber and $26 \%$ for woodworking.

For Petrohan, the cost-based profitability is $185 \%$ for the logging activity, but unlike the Yundola Training forests, at the woodworking works is too low, standing at $9.8 \%$. Profitability on a revenue basis is naturally lower, but it is still at a very high level above $71 \%$ in the timber industry, while the woodworking it is too low falling beyond $9 \%$.

The above gives us reason to suggest that forest managers in FSC forest certification decisions should take into account the profitability of the two main activities: sustainable forest management (logging) and woodworking and the results obtained should be used to search for suitable alternatives before making the final decisions.

\section{References}

Breukink,G., J. Levin, K. Mo (2015) Profitability and Sustainability in Responsible Forestry Economic impacts of FSC certification on forest operators, Jürgen Freund / WWF, p.6, p.48

Simeonova-Zarkin, T., E. Kitchoukov (2018) Forest certification efficiency: analysis of FSC certification benefits and costs in the FME Dospat, Management and Sustainalbe development, 6/2018 (73), pp11-16

http://ec.europa.eu/agriculture/forest/index_ en.htm

http://eur-lex.europa.eu/resource. html?uri=cellar:21b27c38-21fb-11e3-8d1c01aa75ed71a1.0022.01/DOC_1\&format=PDF

Executive Forest Agency, Strategic plan for the development of the forest sector in Republic of Bulgaria 2014-2023

Forest Stewardship Council, A review of Forest Stewardship Council® (FSC $\AA$ ) market developments, statistics, and trends. January 2017

Forest Stewardship Council, Direct benefits, Market Potential of FSC Products. Coming From Smallholder Forestry Operations in Europe, 2010-http://www.cefcoproject.org/ fileadmin/cefco/pdf/6-analysis_of_market_ demand_of_FSC_products-EN.pdf http://info.fsc.org 